\title{
Turkey's Game Plan in Northern Syria and its Implications for the $\mathrm{EU}$
}

\author{
By Zafer Kizilkaya*, Sofie Hamdi ${ }^{ \pm}$\& Mohammad Salman ${ }^{\circ}$
}

\begin{abstract}
Throughout the civil war, the Syrian opposition has been politically and militarily supported by several countries. At present, with its boots on the ground, Turkey is the main backer of the armed opposition in northern Syria. In the region, Ankara envisions a long-term presence which is characterized by a continuous control along the M-4 highway from Idlib in the west to the Iraqi border in the east. This will depend, however, on Turkey's negotiations with Russia and its relations with the US. Meanwhile, the EU has limited its engagement with Ankara, by mainly focusing on the refugee crisis. Yet, divergent views and contesting interests are hindering an effective cooperation between the two on the Syrian "dossier". In light of this, this paper argues that the EU should broaden its perspectives, while establishing permanent contact with Turkey. This necessitates the continuation of the EU's financial support given to Ankara to host refugees; the backing of Turkey in maintaining a frozen conflict situation in Idlib; the increasement of diplomatic engagement in the provision of humanitarian aid; the backing of any effort that aims at ending the hostilities and establishing ceasefires; and the showing of empathy towards Turkish concerns on border security and terrorism.
\end{abstract}

Keywords: Syrian crisis, Turkey, European Union, Northern Syria, humanitarian aid

\section{Introduction}

The Syrian civil war has confronted Turkey with serious security challenges, reminiscent of similar tendencies in the years following the first and the second Gulf war. During the chaotic years in Iraq, Turkey faced a flow of refugees, its security and military establishment became increasingly apprehensive about the emergence of an independent Kurdish entity next to its border and Turkish Armed Forces (TAF) conducted several cross-border operations against Partîya Karkerên Kurdistanê (PKK) (Ata 2008). In that period, Turkey's diplomatic actions prioritized continuous negotiations with Western officials, while it refrained from unilateral actions (Canci and Sen 2011, p. 41). In the Syrian conflict, however, Ankara did not refrain from acting unilaterally. In fact, Turkey wanted to take measures with or without partners and established a permanent presence on the north Syrian soil, despite conflicting the trans-Atlantic interests and a strong condemnation of the West (European Parliament 2019, Yesiltas 2020).

\footnotetext{
*Adjunct Professor, Brussels School of Governance, Free University of Brussels, Belgium. ${ }^{ \pm}$Junior Researcher, Brussels School of Governance, Free University of Brussels, Belgium. Senior Researcher, Brussels School of Governance, Free University of Brussels, Belgium.
} 
Turkey's first military operation in Syria was launched in August 2016. According to Ataman and Ozdemir (2018) ${ }^{1}$, what changed in 2016 were not the fixed objectives in Turkey's Syrian policy, but the priorities among them (2018). The unchanged objectives were: "managing the humanitarian crisis, materializing the fall of the Assad regime, aiding the opposition forces, waging a proxy war with Iran, eliminating the threat of Daesh, and preventing the $\mathrm{PYD} / \mathrm{YPG}^{2}$ from creating an area of dominance" (Ataman and Ozdemir 2018, p. 13). The initial policies prioritized the realization of the first three, while countering Iran was of secondary importance. Over the years, the presence of terrorist organizations and in particular the existence of a PYD-led Administration across its border became the key concern (2018, p. 18). Moreover, the humanitarian perspective of the early years, in the view of Ataman and Ozdemir, became replaced by a realist approach which is characterized by an increased militarist policy in Syria (Ataman and Ozdemir 2018, p. 31).

Without delving too much into the history of Turkey's involvement in the Syrian war, this research report seeks to shed light on Ankara's objectives and long-term strategy in northern Syria. A distinction is made between the dynamics in the west and the east of the Euphrates River, where Turkey confronts different actors whether militarily or diplomatically. After explaining Turkey's actions and plans in the Operation Euphrates Shield (OES) zone, Afrin and Idlib, the paper will decipher Turkey's game plan in the region between Tell Abyad and Ras alAyn - in the east of the Euphrates River. Here, Turkey is not satisfied with the current status quo and the Turkish army continues shelling SDF ${ }^{3} / \mathrm{YPG}$ positions. Finally, the paper will conclude by indicating the potential implications for the EU and by offering concrete policy proposals to implement when engaging Turkey on the "Syrian dossier".

\section{Turkey in the West of the Euphrates River}

\section{Euphrates Shield and Afrin Regions}

Turkey's first military operation in Syria, Operation Euphrates Shield (OES), started on the $24^{\text {th }}$ of August 2016. In seven months and with the participation of nearly 4,000 regular army troops and 7,000 fighters from the Free Syrian Army (FSA), Turkey managed to establish a control between Azaz and Jarablus, $91 \mathrm{~km}$ in width, extending further south to Al-Bab, $30 \mathrm{~km}$ in depth (Yesiltas et al. 2017, p. 22). The operation was aimed at eliminating the presence of Daesh in the vicinity of the Turkish-Syrian border and obstructing PYD's ambitions to annex its autonomous control in the east of the Euphrates with the one in Afrin.

\footnotetext{
${ }^{1}$ Researchers affiliated with SETA: The Foundation for Political, Economic and Social Research, a think-tank with close ties to Turkish President Erdogan's AKP.

${ }^{2}$ Democratic Union Party/Partiya Yekîtiya Demokrat (PYD) and its military wing, People's Protection Units /Yekîneyên Parastina Gel (YPG).

${ }^{3}$ Syrian Democratic Forces (SDF) is a coalition of armed groups in north-eastern Syria and led by YPG.
} 
Initially, the US-led anti-Daesh coalition provided some support to the operation, yet, they became more reluctant when Turkey advanced towards the M-4 highway, captured Al-Bab and set its sights on Manbij (Kasapoglu 2017). Meanwhile, Russia and Iran prioritized the re-control of Aleppo and remained neutral regarding Turkey's advancement towards the city of Al-Bab, before PYD/ YPG could take control. This was mainly in exchange for Turkey's cease of aid to rebel groups in eastern Aleppo (Balanche 2017).

At present, the security situation in the OES zone is somewhat stable, but terror attacks continue targeting civilians and armed groups, particularly in Al-Bab which witnesses sporadic explosions (SYRIAHR 2020). Moreover, the city is critically located on the M-4 highway and the pro-regime forces are only kilometres away from the city center. To the west and east, the armed forces of the PYD-led Administration, the SDF/YPG, control the ground in the cities of Manbij and Tell Rifat. Maintaining territorial control in Al-Bab is thus highly critical for Turkey in order to hinder an enlargement in favour of the Syrian army in Aleppo, while preventing any PYD attempt to connect Tell Rifat to Manbij.

Military-wise, both Tell Rifat and Manbij have long been on the target list of the Turkish Armed Forces (TAF). In the short to medium term, however, an imminent operation against these cities are not expected since both Russia and the Syrian government keep a watchful eye on the developments there. For Damascus, the presence of PYD/YPG in Tell Rifat are considered to provide a buffer between the Syrian Army and the Turkish-backed opposition armed groups, hence contributing to the security in the north of Aleppo city. Manbij, as another PYD controlled city, is the "key to east" for the Syrian government, as the city is located on a route connecting Aleppo to Raqqa and Hasakah (Balanche 2019).

Turkey's second offensive in the city of Afrin in January 2018, was more controversial than the incursion in 2016. In particular, Turkey's approach of targeting the "Kurds" in Syria generated more criticism at the EU-level, which demanded Turkey to prioritize the fight against the UN-recognized terror groups - Daesh, Al-Nusra and other Al-Qaeda like-minded groups (Ayhan 2018). Turkey, however, considered capturing Afrin and thereby eliminating the YPG/ $\mathrm{PKK}^{4}$ from its border as a vital security interest (Yesiltas 2018).

In those days, Russia and Iran were fighting alongside the Syrian army in eastern Ghouta, near Damascus (Al-Hilu 2019, p. 3). Prioritizing the battlefront in rural Damascus and having received a negative response to its demands from PYD to leave control to the Syrian government, Russia is believed to give a green light to Turkish operation code-named "Olive Branch" (Haid 2018). The Russian approval facilitated Turkey's military advances in Afrin and eventually led to Turkey becoming the new ruler of the district since March 2018.

In 2019, some media channels reported that Turkey was building a wall in Afrin in an effort to isolate the Kurds in Afrin from those living in Tell Rifat (Iddon 2019). This was rejected by Turkey which emphasized its endeavour to provide security in the city against PYD/YPG attacks (Al-Khateb 2019). According to Hediye Levent, the construction of the wall between Afrin and Tell Rifat is not

${ }^{4}$ Turkey considers PYD and its military wing YPG as an extension of the Kurdistan Workers' Party (PKK) and hence labels them as terrorists. 
very useful, as there are a lot of underground routes ${ }^{5}$. Ferhat Gurini adds that the wall is mostly a security measure rather than a clear Turkish ambition to isolate Afrin, reminding the permissive attitude of Turkey in allowing the move of a lot of industries from Aleppo to Afrin, especially the lucrative olive oil business ${ }^{6}$.

In both Afrin and the Euphrates Shield (ES) operation zone, Turkey has established a governance model which resembles the city/town/village administration structure within its own municipalities (Al-Hilu 2021, p. 11). Accordingly, ten local councils in the ES region and seven in Afrin govern the large cities and towns, while the neighbouring small towns and villages are administered by subordinate councils. The members of the councils originate from different ethnic and religious groups. Yet, Turkey's security and intelligence establishment keep a close eye on the selection of these members. One Turkish government representative is appointed to each council in an effort to provide collaboration with different Turkish ministries. The administrative responsibility to supervise the governance in the ES region was given to the Turkish cities of Gaziantep and Kilis, while the city of Hatay oversees the functioning of the councils in Afrin (Al-Hilu 2021, p. 11).

Meanwhile, Turkey has heavily invested in infrastructure. It has built, renovated, and opened schools, hospitals, courthouses, post-offices, and other buildings for public use. As a currency, Turkish lira has been in use since June 2020 (Al-Hilu 2021, p. 15). The councils receive their budget from the Turkish governorate that is in charge of overseeing them. The main sources of income are coming from agriculture, border-crossings, and trade, mostly exports from Turkey and a small-scale but "conspicuous trade with regime-held areas in Aleppo and the SDF areas in Manbij" (Al-Hilu 2019, p. 15).

For Turkey, the governance model established in the regions of ES and Afrin are success stories. With effective central planning and "on-site execution" involving all relevant state institutions, non-governmental organizations (NGOs) and key local actors, Turkish authorities believe that they have put in place a wellfunctioning administrative system that provides services in the sectors of "justice, education, health, and development" (Aslan 2019, p. 61). Moreover, in Turkishcontrolled regions, the prices of some essential food items such as bread, tomatoes, potatoes, onion, and cucumber are cheaper than those in government or SDF/YPG controlled areas - a source of pride for Turkish authorities (Suriye Gundemi 2021).

A February 2021 New York Times (NYT) article indicated some hints indicating that Turkish official claims of bringing peace, welfare and stability to north-western Syria are not completely baseless (Gall 2021). Despite displacing hundreds of thousands of Kurds from Afrin and attracting criticism from the international community for launching offensives on foreign territory, Gall points to the reality of Turkey's role in providing safety to "some five million displaced and vulnerable civilians" in northern Syria (2021). For some, the arguments of Gall in her NYT article are highly controversial, due to her portrayal of a onesided view of the complex situation in Afrin — neglecting the peaceful situation in

\footnotetext{
${ }^{5}$ Interview with Hediye Levent, a freelance journalist (Damascus).

${ }^{6}$ Interview with Ferhat Gurini, a freelance journalist based in London.
} 
the city before Turkey's intervention, human rights of violations committed by Turkish-backed armed groups and the lack of "women" and "Kurdish" representation in governance (Frantzman 2021, SYRIAHR 2021).

On the one hand, it is true that Turkey has not totally acted for humanitarian reasons in Afrin or elsewhere in northern Syria. It has also pursued vital national interests such as preventing additional refugee flow and destroying PYD's ambitions of autonomous rule. On the other hand, the Syrians in the Turkishcontrolled regions only have Turkey as the source of protection, considering the fact that the majority of them do not have any chance to return to their hometowns in the near term. In particular, for those who have fought alongside the Free Syrian Army or other opposition-armed groups - together with their families, Turkishcontrolled areas remain the only viable option to carry on their lives. They are not welcome by the government in Damascus and for Turkey, it is better to keep and manage these armed people within Syrian territory rather than inside Turkey.

In the regions of ES and Afrin, Turkey wants to create life conditions that are better than the ones in the areas administered by the Syrian government or SDF. As a matter of fact, all the key actors on the ground in Syria seek to ameliorate the safety, security, and prosperity of the areas under their governance, while trying to damage the reputation of their enemy in their own zones. For Turkey, the incessant car bomb-attacks and explosions conducted by YPG/PKK linked groups in the cities of Azaz, Al-Bab or Afrin are aimed to deteriorate the positive image of Turkey in bringing stability to the regions of ES and Afrin (Acun 2021). Likewise, the Turkish authorities believe that the Russian missile attacks, which have sporadically targeted oil tankers and primitive oil loading facilities in the vicinities of Jarablus and Al-Bab - twice happened in March 2021 — seek to damage the daily economic life in these regions (Cookman and Hezaber 2021, Ozkizilcik 2021).

Despite these explosions and attacks, Turkey appears determined to maintain and improve the governance model it has established in the regions of ES and Afrin. If he could, the President of Turkish republic, Recep Tayyip Erdogan would want to replicate a similar model in the province of Idlib. Nevertheless, here, the situation is more complex, and Turkey needs to avert any additional pro-Syrian government offensive in the vicinity of the M-4 highway. Moreover, it also has to deal with the threat coming from the Al-Qaeda linked terrorist groups and restrain the aspirations of Hayat Tahrir al-Sham, HTS — "a former Al-Qaeda affiliate" (Khalifa and Bonsay 2021).

\section{Idlib}

Turkey's military presence in Idlib is different from the other operation zones in three ways. First, in this province, rather than launching a unilateral military intervention with clear start and end days, Turkey gradually deployed military troops after the agreement with Russia and Iran in the Astana platform in September 2017. Accordingly, Turkey established 12 observations posts between October 2017 and May 2018 to monitor the ceasefire (Suriye Gundemi 2018). Second, the Astana process provides a certain level of legitimization to Turkey's 
military presence on the Syrian soil. In addition to the tripartite of Russia, Iran and Turkey, the talks also involve representatives of international organizations and delegations from the Syrian government and the opposition (Semenov 2021). Finally, together with the other sponsors of the Astana forum, Turkey committed itself to de-escalate the situation in Idlib and to deal with the extremist groups in the province - a welcome development for the international community (Crisis Group 2018).

However, the establishment of military posts did not ease the tensions in Idlib. In September 2018, Putin and Erdogan agreed in Sochi on the creation of a 15-20 $\mathrm{km}$ deep demilitarised zone in the vicinities of the M-4 and M-5 highways and the elimination of all radical terrorist groups from this area (Baresh 2019, p. 24). Nevertheless, the Syrian army, which is supported by Russia and Iran, did not cease its military operations along the M-5 highway by using the pretext of fighting against terrorism. As a result, the opposition armed groups gradually lost territorial control in Idlib - going down from more than 9,000 sq km in September 2017 to 7,000 sq km in April 2019 and to nearly 3,000 sq km in March 2020 (Balanche 2020b). In this context, Putin and Erdogan concluded a new ceasefire agreement on 05 March 2020 and agreed to establish a security corridor along the M-4 highway, stretching $6 \mathrm{~km}$ to the north and $6 \mathrm{~km}$ to the south (Soldatkin and Kiselyova 2020).

In Idlib, the Turkish government appears determined to preserve the statusquo reached after the March 2020 agreement with Moscow. Turkish officials do not want to see the happening of a similar scenario of the M-5 highway in which the pro-regime forces gradually enlarged their territorial control by capturing the critical cities of Khan Shaykhun, Ma'arrat al-Nu'man and Saraqib between August 2019 and March 2020. Ankara fears that any step back from the March 2020 frontlines may trigger additional losses, not only in Idlib, but also in the other Turkish controlled districts of Afrin, Azaz, Jarablus or Al-Bab (Kardaş 2020). Therefore, Turkey deployed a troop size of 10-15,000 soldiers mostly in the north of the M-4 highway and the Jabal Al-Zawiya region in the southern countryside of the Idlib province.

As of March 2021, Turkish mass military presence has played a certain level of role in halting the violence and deterring the Syrian Army from launching a new offensive. Nevertheless, there are also other key factors that restrict the Syrian government's room of manoeuvre in Idlib, such as the deteriorating economic conditions in the country, which is hit by the Western sanctions; a re-emergent Daesh threat in the central and eastern parts of Syria; and more importantly, the position of Russia which does not appear to have an appetite in damaging its bilateral relations with Turkey (Waters 2020).

Syria is just one of the battlegrounds where Ankara and Moscow support different conflicting sides and confront each other indirectly - like in Libya and Nagorno-Karabakh. Yet, both capitals continue their "uneasy cooperation" and avoid direct political or military confrontation to resolve differences (Borshchevskaya 2020). From time to time, Russia uses the fragile situation in Idlib as a leverage against Turkey. Most recently, on 21 March 2021, Russian warplanes and ballistic missiles targeted a fuel facility and a truck park near the 
"densely populated refugee camps" in the towns of Qah and Sarmada at the Turkish border (Al-Khalidi 2021). With such attacks, Russia reminds Ankara that it has the upper hand in the bilateral relations and that it can always trigger additional refugee flows from north-western Syria to Turkey, by worsening the economic and security conditions in the Turkish controlled areas.

Previous cycles of escalation and de-escalation in Idlib have resulted in the enlargement of territories which fall under the control of Damascus. The March 2021 attacks of Russia and Syrian Army's continued artillery fire in the southern countryside of Idlib could also be a harbinger of additional pro-regime offensives. These can happen in the spring or summer of 2021, immediately after the presidential elections in the Syrian Arab Republic — which will most likely keep Bashar al-Assad in power for another seven years. Nevertheless, Russia needs to carefully assess the benefits and costs of a new military operation in Idlib, considering the significant Turkish military build-up and the economic and security-related challenges faced by the Syrian government. At some point, as Sam Heller mentions, Russia may enable the Syrian government "to seize the M-4 [Latakia-Aleppo] highway in Idlib and the areas south of it", but this requires some kind of horse-trading between Ankara and Moscow - which can happen on the status of some critical SDF controlled cities such as Tell Rifat, Manbij, Ain Issa or Tell Tamr (Medina 2020).

In addition to dealing with the Russians on the fate of Idlib, Turkey has another key challenge in this province which is caused by the dominant position of the extremist groups. Among them, with nearly 10,000 fighters and through its close influence over the Salvation Government that governs the majority of Idlib, Hayat Tahrir al-Sham (HTS) is the most dominant entity (UNSC 2021). Despite the fact that HTS is recognized as a terrorist group by Russia, the United States, the United Nations and Turkey, the group has increased its efforts to distance itself from Al-Qaeda in the last couple of years. This is mostly done by pursuing a more local agenda which focuses on the establishment of its own authority governed by the sharia law and by fighting the more transnational focused jihadist groups (Khalifa and Bonsey 2021, UNSC 2021). To increase its legitimacy, HTS has also eschewed targeting Turkish or Russian military observation posts in the Idlib deescalation zone.

Meanwhile, Turkey has adopted a rather pragmatic approach against HTS. By seeing the entrenched position of HTS in Idlib and its capability to contain other extremist groups, Ankara has refrained from a direct military confrontation with HTS. For the Turkish officials, resorting to arms against this group — which have mostly recruited young local fighters in its ranks - will destabilize Idlib, weaken the strength of the opposition against the threat of pro-regime offensives, and trigger an additional refugee flow towards Turkey (Crisis Group 2020, p. 16). HTS has also benefitted from Turkey's active military presence in Idlib, as it prevented further pro-regime advances that could harm HTS's achieved gains in this province. 
According to Dries Lesage, Ankara also believes that extremist groups in Syria have largely been fostered by Assad's repression. ${ }^{7}$ This falls in line with Turkey's stance to not consider them all as equals to Al-Qaeda or Daesh against whom you can only achieve something with a military approach. Instead, Turkey has tried to steer the pragmatic rebels away from the more radical positions in order to make them more controllable. From the early days of its troop deployment to Idlib, Ankara's approach to deal with HTS was to "engage to control and divide" (Lister 2020).

Turkish attempts to sow discord among the radical factions paid off with the formation of Hurras al-Din (HAD) in February 2018 - "a coalition of jihadist groups who defected from HTS after its public distancing from Al-Qaeda in July 2016" (Moubayed 2020). According to UN figures, HAD has between 2,000 and 2,500 fighters (UNSC 2021). In 2020, this Al-Qaeda affiliate suffered significant losses as a result of HTS's crack down on the group, as well as the US airstrikes (Schmitt 2020). In Idlib, there are several other terrorist groups which have thousands of foreign terrorist fighters in their ranks such as the "Khattab AlShishani Brigade (Chechen fighters), Katiba al-Tawhid wal-Jihad (KTJ, Central Asian fighters) and the Eastern Turkistan Islamic Movement (ETIM)" (UNSC 2021).

In the short term, Turkey desires to ensure that none of the former or current Al-Qaeda affiliates endanger the lives of its soldiers that are stationed in the Idlib province. Moreover, Ankara is extremely concerned about the stability in this region which is home to an estimated 3-3.5 million people - majority of whom are living in the center and northern parts of Idlib in the vicinity of the Turkish border. In the medium to long-term, however, Turkey desires to see the dissolution or elimination of HTS and other radical groups in line with the mutually agreed decisions with Russia - last on 05 March 2020 in Moscow.

Ideally, Turkish authorities would wish for a situation where HTS "rebrands and merges into an evolved form of the Syrian National Army (SNA)", the coalition of armed opposition groups that are backed and supervised by the Turkish military (Lister 2020). Nevertheless, this does not appear to be an easy task. HTS aspires to consolidate its military and political control in Idlib (Erkmen 2020). Moreover, the group is reported to have plans to expand in northern Aleppo - towards the Olive Branch and Euphrates Shield areas - pointing at the security failures in these regions, including sporadic explosions and deaths (AlKhateb 2021). In such a setting, it is likely that it will be good enough for Ankara to preserve the status quo in Idlib, in which HTS contains the other radical groups, while Turkey blocks additional pro-regime offensives via its diplomatic talks with Russia, as well as through its mass troop deployment along the M-4 highway.

Finally, on the living conditions of the people in Idlib - majority of whom have been internally displaced at least once during the conflict — Turkey has a clear strategic objective: keeping them inside Syria and not adding to the 3,6 million Syrians already living in Turkey. Ankara is not only concerned about the economic burden of hosting additional ordinary civilians but is also wary of

${ }^{7}$ Interview with Dries Lesage, Associate Professor of Globalization and Global Governance at Ghent University, Belgium. 
accommodating armed people that belong to secular, religious or extremist opposition groups. As Dries Lesage argues "the loyalty to the Syrian rebels is very important for Turkey as they cannot go back to the region they originally come from. As a result, they must be resettled somewhere else, but not in Turkey". 8 Hediye Levent adds that the number of militias goes up to tens of thousands and including their families, it is a huge number that Turkey cannot absorb and control. ${ }^{9}$ Therefore, Turkey needs to employ them inside Syria or in other regional battlefronts. This helps Ankara to exert authority in its controlled regions in northern Syria. Moreover, it provides Turkey the means to apply an assertive military posture, helping the country to introduce itself as a key power in shaping regional politics.

\section{Turkey in the East of the Euphrates River}

Turkish military conducted its first and only large-scale military operation in the East of the Euphrates River - Operation Peace Spring (OPS) - in October 2019. About two weeks earlier before the start of OPS, Turkish President Erdogan presented a map to the UN General Assembly where he proposed to establish a safe zone of $480 \mathrm{~km}$ wide and $30 \mathrm{~km}$ deep, stretching along the M-4 highway in north-eastern Syria (Yackley 2019). According to Erdogan, initially 1 to 2 million Syrians could be resettled in this safe zone with the possibility to extend it further south - to Raqqa and Dayr Az Zawr — which could then increase the number to 3 million (Temizer et al. 2019).

The proposed safe zone included Manbij in the west and the Yarubiyah border crossing in the east. In Erdogan's mind, the M-4 highway could delineate the new border and had to remain within the safe zone in order to prevent its use by PYD/YPG for trade and logistic purposes (Temizer et al. 2019). After President Trump's decision to withdraw the American troops from the region, Turkish military launched its offensive — code named Operation Peace Spring (OPS) taking a concrete step in realizing some of Erdogan's plans for north-eastern Syria. In less than ten days, Turkish army units gained control over a stretch of land between Tell Abyad and Ras al-Ayn, which is approximately $120 \mathrm{~km}$ wide. The Turkish military operation had to stop after US and Russian diplomatic intervention in which Turkey was guaranteed on the removal of PYD/YPG $30 \mathrm{~km}$ away from the Turkish-Syrian border (Uras 2019).

Despite achieving significant gains in distancing PYD/YPG from its immediate border, Turkey has two un-met expectations in the aftermath of the Peace Spring Operation. First, Turkish Army could not expand its control towards the M-4 highway. Here, Turkey eyes for the towns of Ain Issa and Tell Tamr, as they are critically located on the southern edges of the Turkish-controlled region. Second, Turkey desires to extend the $120 \mathrm{~km}$ wide corridor and create a safe zone that stretches along its $911 \mathrm{~km}$. border with Syria. In other words, Turkey wants to

\footnotetext{
${ }^{8}$ Interview with Dries Lesage.

${ }^{9}$ Interview with Hediye Levent.
} 
establish a new de-facto border with Syria, running mostly in parallel with the M-4 highway.

As of March 2021, Russian and American political interests and military presence in north-eastern Syria have blocked Turkey from achieving the aforementioned objectives. The region is also critical for the government in Damascus since it includes major oil fields and is rich in agricultural products such as grains and cotton (Gurbuz 2018). Regardless of Syrian government's position and that of Iran included, Ankara believes that without the US and Russia in the equation, Turkey could easily clear PYD/YPG from north-eastern Syria (Alptekin 2021). In the current settings, however, Turkish authorities appear to have realized the difficulty in setting up a Turkish-controlled safe zone all over northern Syria, which is eventually the broader strategic objective.

In order to accomplish the smaller goal, especially from December 2020 onwards, Turkish artillery has intensified its shelling of the towns of Ain Issa and Tell Tamr and Turkish-backed factions have attacked several villages in the surrounding areas of Ain Issa (Abdulrazek 2021). Here, Turkey desires to isolate the town of Ayn al-Arab (Kobane), by cutting its connection to Raqqa in the south and to Hasakah in the east. Russia, on the other side, is using the Turkish pressure as a stick to convince PYD to hand over more territories to the Syrian government in north-eastern Syria. All in all, in the short to medium term, it is likely that Turkey and Russia will have some kind of a shared control along the M-4 highway between Ain Issa and Tell Tamr — with Turkey securing the north while Russia acting as a guarantor over the road and in its south.

In the medium to long-term, Ankara is not expected to relinquish its broader strategic objective in north-eastern Syria. In March 2021, in an op-ed written for Bloomberg, President Erdogan pointed to Turkey's critical role in constructing accommodation facilities for the displaced people within Syrian territory. Once again, he referred to his plan which he presented at the UN General Assembly in September 2019 (Erdogan 2021). It is true that, for a while, Turkey had to put its plans to enlarge the OPS zone on the shelf. Nevertheless, if and when conditions permit, additional Turkish offensives in north-eastern Syria cannot be ruled out.

Ayn Al-Arab (Kobane), in the west of Tell Abyad, was already on the potential target list before the conduct of the OPS. Likewise, Turkey has long been interested in Manbij — west of the Euphrates River. Military-wise, extending the Peace Spring operation zone to the east will be more problematic than widening it towards Kobane or Manbij, considering the US military presence there and PYD's more established position in cities such as Hasakah, Qamishli and Derik. Moreover, on the Turkish side of the border, Ayn-Al Arab, Tell Abyad and Ras-al Ayn are neighboured by Gaziantep and Urfa. Going further east, Qamishli and Derik border with the predominantly Kurdish cities of Nusaybin and Cizre. Because of the large Kurdish presence in the proximate cities, deploying Turkmen or Arab armed groups will be more difficult in the east of Ras-Al Ayn.

Concerning PYD/YPG's position in confronting Turkey in the north-east, the biggest advantage is the role played by Russia and the US in deterring big-scale Turkish army offensives. However, a big challenge for the group is the position of the Arab militias within the SDF which have not been very eager to remain 
involved in Ankara's fight with the PYD/YPG (Balanche 2020a). Turkey, in turn, hopes for additional losses for PYD/YPG, as this may create tensions in the alliance of SDF and weaken PYD's status in the cities of Manbij, Raqqa and Dayr Az Zawr (Orhan 2019, p. 8). Meanwhile according to Oytun Orhan, Ankara considers it as a vital security interest to fully eliminate PYD and without achieving this, Turkish army will not retreat from Syrian territory (2019, p. 9).

Finally, on the administration of the Peace Spring region, it is important to note Turkey's establishment of the "Syria Support and Coordination Centre (SUDKOM)" under the governorate of Sanliurfa. Together with his deputy governors, Sanliurfa governor is supervising the public administration in the areas of Tell Abyad and Ras al-Ayn, normalizing the conditions for the civilians by offering services in education, healthcare, justice and in the other aspects of social life (SUDKOM 2021). The internal security is provided by the police force which has been trained and equipped by Turkey in the towns of Tall Abyad and Ras alAyn (Al-Hilu 2021, p. 7). A weakened Turkish economy has introduced certain challenges in accomplishing a full-scale reconstruction of the OPS region when compared to other Turkish-controlled safe zones in the west of the Euphrates River. Nevertheless, the responsible governor, Abdullah Erin, regularly visits the towns of Tell Abyad and Ras al-Ayn and tries hard to mobilise funds from "Arab and Islamic foundations" in order to develop conditions in this region (Al-Hilu 2021, p. 14).

\section{EU-Turkey Relations in Light of the Developments in Syria}

Ten years after the Syrian uprisings emerged, Turkey and the EU have some shared concerns, intersecting positions, and converging interests on the developments in Syria. These are: ending the violence and enabling the start of a political process in line with the UNSC Resolution 2254; establishment of a "transitional governing body" which represents the entire Syrian society (UNSC 2012); curbing the refugee flow from Syria; fighting extremism and countering the terrorist threat caused by Daesh, Al-Qaeda and like-minded groups; supporting the refugees and internally displaced people (IDPs); and ensuring the continuation of humanitarian assistance to the Syrians who are in need. Nevertheless, there are three topics on which the EU and Turkey have divergent views and contesting interests, and thereby hindering an effective cooperation between the two on the Syrian "dossier". These three are: the EU's concerns about Turkish military operations within the Syrian territory; contrasting views on the position of PYD/YPG; and the migration crisis which witnessed Erdogan's "weaponization of refugees" in response to what he considers a lack of solidarity from the EU (Jennequin 2020).

First, there has been some scepticism at the EU level about Turkey's real intentions in Syria following the first two large-scale operations - the Euphrates Shield in 2016 and 2017, and the Olive Branch in 2017 — but the EU institutions and countries were most vocal in the wake of the Operation Peace Spring which was conducted in October 2019. The harshest criticism came from the European 
Parliament when its President, David Sassoli, called the Turkish offensive as an "act of war" (Stanicek 2019, p. 3). In a joint statement, the EU Council condemned Turkey's unilateral action and called for Turkey to prioritize the fight against Daesh rather than opening up a new battlefront in Syria and thereby creating more instability (Del Torre 2019). The EU countries also agreed to limit the sales of arms to Turkey, yet without deciding on the implementation of an EU-wide embargo against Ankara (Emmott 2019). Nevertheless, Turkey remained adamant on the justness and timeliness of its operation, by explaining that it was "conducted in line with the country's right to self-defence borne out of international law", in an effort to establish a safe corridor that protects Turkey from the "YPG terrorists" (Daily Sabah 2019).

Second, Turkey considers PYD and its armed wing YPG as an offshoot of the terrorist group PKK. For Ankara, the affiliation between PYD/YPG and PKK is very clear. The Turkish Ministry of Foreign Affairs stresses in its official website that "PYD/YPG was set up under the control of PKK terrorist organization in 2003" and both entities "share the same leadership cadres, organizational structure, strategies and tactics, military structure, propaganda tools, financial resources and training camps" (MFA Turkey 2021). For the EU, the US, and many European countries, however, PYD/YPG contributed significantly to the fight against Daesh. Despite designating PKK as a terrorist entity, neither the US nor the EU attaches the same label to PYD/YPG. This constitutes a continuous source of friction between Turkey and the West, which is unlikely to change under Erdogan's leadership, considering the alliance he has developed domestically with the nationalist and religious political parties in the last couple of years.

Finally, the refugee crisis, with its peak in 2015, added a new dimension to the relationship between Turkey and the EU. To curb the refugee flow to Europe, the EU and Turkey agreed on a refugee deal in 2016. The EU promised to pay $€ 6$ billion to Turkey in return for the latter's acceptance of hosting refugees and the blocking of illegal migration to European territories. In December 2020, the EU concluded the contracting of the initially promised amount of $€ 6$ billion, but considering the continued need, in July 2020, the EU released an additional $€ 485$ million to "support refugees and host communities in Turkey" (European Commission 2020).

Despite some criticism coming mainly from human rights activists, the refugee agreement achieved success in reducing the numbers of migrants flowing into European territory and the EU, at the institutional level, has remained committed to it (VanOpdorp 2020). The deal, however, experienced a real stress test at the end of February 2020, following an escalation of violence in Idlib and the death of more than 30 Turkish soldiers in an airstrike. On 28 February, Ankara declared that Turkey could not deal with the dire humanitarian situation in northern Syria alone, pointing to 900,000 people who have been displaced in Idlib in less than a year. For Turkey, in such a setting, Europe had to share the burden and stated that the actual conditions in north-western Syria compelled Ankara "to open its borders to refugees hoping to leave for Europe" (Mutter 2020). For a couple of days, international attention was given to thousands of refugees who flooded Turkey's border with Greece, some travelling freely with buses arranged 
by Turkish officials (Gridneff and Gall 2020). In a speech on 11 March, Erdogan once again threatened the EU and said "with the warming of the weather in the spring, the influx of irregular migrants heading to Europe will not be limited to Greece but spread all over the Mediterranean" (France24 2020).

For several days, the miserable views at the EU's border with Turkey, where the migrants clashed with the Greek riot police continued. In the second half of March 2021, the EU countries and Turkey became hit by the Covid-19 pandemic, sweeping all other major issues under the carpet. In the following period, both Turkey and the EU refrained from escalating the tensions surrounding the refugee crisis. On the one hand, the 05 March 2020 Ankara-Moscow agreement reduced the level of violence in Syria. On the other hand, the Turkish-EU relations witnessed other serious challenges - such as the Eastern Mediterranean crisis, Turkey's oil drilling activities in the Mediterranean, and the tensions between Turkey, Greece and Cyprus over the maritime boundaries — pushing the migration issue into the background.

Will Turkey once again use the refugees as a weapon in its relations with the EU? Will Erdogan re-open Turkey's border with the EU when new clashes erupt in northern Syria? There are no easy and definite answers for these questions. Most likely, Turkey's attitude will be affected by several other factors than the developments in Syria. Nevertheless, based on some hints Erdogan has given in a recent op-ed - written for Bloomberg in March 2021 - it couldn't be wrong to assume that Turkey will adopt a similar approach when faced with additional challenges in its Syria policy.

In the tenth year of the Syrian uprising and a year after Turkey agreed a ceasefire with Russia in Idlib, in his Bloomberg article, Erdogan stated that the international community in general and the West in particular, forgot about the humanitarian crisis in Syria as a result of the global pandemic. Erdogan praised over Turkey's success in stopping the human suffering in Syria by creating the safe zones and by investing in them. According to the Turkish leader, the Turkishcontrolled areas in northern Syria "have become islands of peace and stability, as well as self-sustaining ecosystems" (Erdogan 2021). In Turkish President's mind, Ankara's policy decisions and actions in northern Syria have prevented irregular migration and countered terrorism, thereby contributing positively to the political stability in Europe.

Thereafter, Erdogan proposed three different courses of actions for the West to follow on the Syrian crisis. The first alternative is pretty much sticking to the current policies by staying on the sidelines while the human suffering continues in Syria. The second option is a 180-degree shift and includes a full engagement by using military, economic and diplomatic tools. As Erdogan stresses, this is not likely to happen given the EU's stance on the Syrian uprising in the last decade. Finally, what Erdogan designates as the best course of action is for the West "to throw their weight behind Turkey and become part of the solution in Syria, at minimum cost and with maximum impact" (Erdogan 2021).

Here, Erdogan lists three demands from the West and the EU: first, the West needs to understand Turkey's concerns about PYD/YPG and take a clear position against this terrorist entity; second, the Western countries need to fulfil their 
responsibilities to address the humanitarian crisis in Syria; and third, the West should endorse Turkey's creation of safe zones in Syria and invest in these zones to improve the living conditions of the IDPs (Erdogan 2021). For the Turkish President, the failure to support Turkey and share the burden in alleviating the humanitarian crisis in Syria, could trigger new waves of migration towards European countries.

Erdogan's messages are rather clear. In the next crisis, he will most likely remind the EU leaders about his Bloomberg article. Quite possibly, he will adopt a "I have told you" attitude, unless he sees the level of support he wishes for. For Erdogan, meeting Turkey's demands will not be difficult for the West ("minimum cost") and in return, Turkey will confront the pro-regime camp, continue its support for the Syrian opposition, preserve the frozen conflict situation, stop irregular migration, and deal with the religious terrorist threat in Idlib - all beneficial for the security of the EU ("maximum impact").

The EU institutions have not officially reacted to Erdogan's Bloomberg article. It is likely that the EU is not considering substantial changes in its Syrian policy. As the EU High Representative Josep Borrell stated on the 10th anniversary of the Syrian conflict on 15 March 2021, the EU "has not changed its policy as outlined in previous Council Conclusions", remains committed to "the unity, sovereignty and territorial integrity of the Syrian state" and desires to see the occurrence of a political transition which will establish an inclusive governance for all Syrians, in line with the UN Security Council Resolution 2254 (Borrell 2021).

In the short-term, the EU will likely continue cooperating with Turkey in the provision of support to the refugees inside Turkey. An extensive EU engagement with Ankara on the Syrian "dossier" and "throwing the weight behind Turkey" as Erdogan requests, is not likely to happen given the complex dynamics on the Syrian battlefield with Damascus, PYD/YPG, Russia, Iran, and the US having divergent security interests. In such a setting, the EU will most likely stick to its current position, which Erdogan identifies as watching from the sidelines.

\section{Conclusion and the Implications for the EU}

From the early days of the Syrian uprising and the conflict, Turkey adopted a very active foreign and security policy in Syria. Ankara wanted to be the key actor in the establishment of a new political order in Syria. However, the extensive Russian military support after September 2015 resulted in significant gains for the government in Damascus and in the ensuing period, Turkish officials became less vocal about the removal of Bashar al-Assad from power. Especially in the aftermath of the first military operation in August 2016, Turkey's primary security concern has been to block any PYD/YPG effort to form a continuous territorial control along the Turkish border with Syria.

As of April 2021, Turkey has three key strategic objectives in Syria. First, to create a region in northern Syria which is ruled by friendly forces and not by any Kurdish group which is affiliated with the ideology of the PYD/YPG/PKK; second, to establish a certain level of control along the M-4 highway, stretching 
roughly from Idlib in the west to the Iraqi border in the east; and third, preserving the established status quo in the west of the Euphrates while changing it in the east of the river - Ankara desires to weaken PYD/YPG in north-eastern Syria by limiting its access to the M-4 highway and by cutting its connections between the regions of Ayn al-Arab, Hasakah and Raqqa.

Even if a governmental change happens in Turkey in the upcoming years, the country will likely stay in Syria by either the presence of the Turkish army or by local armed groups which are an expansion of Turkey. Turkish armed forces will unlikely retreat from the Syrian soil without securing security and political guarantees for the Syrian IDPs and without ensuring the elimination of the terrorist threat which is primarily attributed to PYD/YPG's links with PKK. In brief, the European leaders need to understand that Turkey is there to stay in Syria. Moreover, to end PYD/YPG's territorial control in northern Syria, Turkish army may launch additional operations when conditions permit. To eliminate PYD/ YPG, Ankara will seek to break away the Arab components of the Syrian Democratic Forces (SDF), increase talks with the Kurdish rivals of PYD in Syria and Iraq, and continue to isolate the group from the international peace negotiations in Geneva (Yesiltas 2019).

Therefore, the EU should consider taking the following practical steps, when engaging with Ankara on the developments in Syria. First, the EU and Turkey have to continue addressing common interests. This necessitates the continuation of the EU's financial support given to Turkey to host refugees. Especially with a potential reduction in the spread of the Covid-19, the movement of migrants might increase again. Brussels and Ankara should work together to ameliorate the living conditions of millions of displaced people who are living in the camps/tents in Idlib and elsewhere in northern Syria. In providing help to the Syrian refugees and IDPs, the EU should make sure that the process is transparent, not allowing Turkey to favour certain NGOs or other aid organizations.

Second, and linked to first one, the EU has to ensure the continuation of a frozen conflict situation in Idlib. This requires an increased engagement on the EU side with the Astana trio of Russia, Iran, and Turkey. The EU may have certain doubts and concerns about Turkey's military presence in northern Syria - in Afrin and on the east of the Euphrates river in particular — but in Idlib, Turkey's military actions serve two beneficial purposes for both Ankara and Brussels: containing the terrorist threat and blocking any additional pro-regime advances, which could trigger additional refugee flows.

Third, the EU and Turkey should increase diplomatic engagement in the provision of humanitarian aid. In recent years, Russia and China have tried to centralize the humanitarian aid provision in Damascus, by limiting the number of open crossings that could be used for UN humanitarian assistance provision. Currently, only one border crossing, Bab al-Hawa in north-western Syria, is authorized since Russia and China had previously vetoed the use of other crossings in the Syrian border with Iraq, Turkey, and Jordan (Lister and Feltman 2021). Another vote is scheduled at the UN Security Council in July 2021 and Russia may push for the closure of the existing access point in Bab-al Hawa. Considering the dire living conditions in northern Syria, the EU and Turkey can 
mobilize diplomatic support to prevent such a scenario and if possible, they could also insist on the opening of Bab al-Salam, which would improve the life standards of the Syrians living in northern Aleppo.

Fourth, in resolving the Syrian conflict and establishing a durable peace in the war-torn country, the EU should back any effort that aims at ending the hostilities and establishing ceasefires. Brussels can "increase its visibility in the UN-led Geneva process", while engaging more with the Astana tripartite of Russia, Iran, and Turkey (Kizilkaya et al. 2021). The almost frozen conflict situation in Syria is making the socio-economic problems much more visible and the Astana forum does not appear to have the resources nor the knowledge to deal with these. The EU institutions could play a role by bringing forth the expertise of their officials on the socio-economic issues and engage with Turkey and others to improve the life standards of Syrians who are living in territories controlled by different actors (Kizilkaya et al. 2021).

Finally, the EU needs to understand and show empathy towards Turkish concerns on border security and terrorism. In Turkey, there is a strong antipathy towards PKK and any group that is somehow linked to it. The EU should not eschew from condemning any reported human rights violations against any ethnic group in Afrin, Ras al-Ayn or elsewhere in Syria, but it has to recognize that Turkey does not have an agenda to ethnically cleanse the Kurds, especially the practicing Muslim Kurds who do not support PKK or PYD/YPG.

\section{Acknowledgments}

The Centre for Applied Turkey Studies (CATS) at Stiftung Wissenschaft und Politik (SWP) in Berlin is funded by Stiftung Mercator and the Federal Foreign Office. CATS is the curator of CATS Network, an international network of think tanks and research institutions working on Turkey. "Syria: Risks and Opportunities for EU-Turkey Cooperation" is a project of CATS Network.

\section{References}

Abdulrazek S (2021, January 5) Turkey establishes new base, Shells Syria's Ain Issa countryside. Asharq al-Awsat.

Acun C (2021) ABD Seçimlerinin Suriye'de Ciddi Etkileri Var (The US elections have serious implications for Syria). Retrieved from: https://www.setav.org/abd-secimleri nin-suriyede-ciddi-etkileri-var/. [Accessed 15 March 2021]

Al-Hilu K (2019) Afrin under Turkish control: political, economic and social transformations. Research Project Report RSCAS/Middle East Directions 2019/10. European University Institute.

Al-Hilu K (2021) The Turkish intervention in Northern Syria: one strategy, discrepant policies. European University Institute. Research Project Report RSCAS/Middle East Directions 2021/01.

Al-Khalidi S (2021, March 21) Russian jets hit gas facilities and civilian areas near Turkish border, witnesses and rebels say. Reuters. 
Al-Khateb K (2019, May 16) Turkey denies it's building wall around Afrin. Al-Monitor.

Al-Khateb K (2020, January 25) Hayat Tahrir al-Sham challenges FSA in Northwestern Syria. Al-Monitor.

Alptekin H (2021) Suriye'nin Kuzeyinde Neler Oluyor? (What is going on in northern Syria?) Retrieved from: https://www.setav.org/suriyenin-kuzeyinde-neler-oluyor/. [Accessed 26 March 2021]

Aslan M (2019) Turkey's reconstruction model in Syria. SETA Publication 139.

Ata FK (2008) Turkey's trans-border operations in Northern Iraq: before and after the invasion of Iraq. Research Journal of International Studies 8.

Ataman M, Ozdemir C (2018) Turkey's Syria policy: constant objectives, shifting priorities. Turkish Journal of Middle Eastern Studies 5(2): 13-35.

Ayhan H (2018) SD ANALYSIS - The Operation Olive Branch and the EU. Retrieved from: https://www.sde.org.tr/analysis/sd-analysis-the-operation-olive-bran ch-andthe-eu-analizi-8142. [Accessed 23 February 2021]

Balanche F (2017) Syria conflict: what is at stake in the battle of al-Bab? Retrieved from: https://www.bbc.com/news/world-middle-east-38939492 [Accessed 19 January 2021]

Balanche F (2019) For Assad, Manbij is the key to East Syria. Washington Institute Policy Watch 3072.

Balanche F (2020a) The fragile status quo in Northeast Syria. The Washington Institute for Near East Policy. Policy Watch 3343.

Balanche F (2020b) Idlib may become the next Gaza Strip. The Washington Institute for Near East Policy. Policy Watch 3288.

Baresh M (2019) The Sochi agreement and the interests of Guarantor States: examining the aims and challenges of sustaining the deal. European University Institute Middle East Directions 2019/01.

Borrell J (2021) Ten years of conflict in Syria. Retrieved from: https://eeas.europa.eu/dele gations/senegal/95007/ten-years-conflict-syria_en. [Accessed 28 March 2021]

Borshchevskaya A (2020, August 6) Moscow and Ankara will continue uneasy cooperation. Middle East Institute.

Canci H, Sen SS (2011) The Gulf War and Turkey: regional changes and their domestic effects (1991-2003). International Journal on World Peace 28(1): 41-65.

Cookman L, Hezaber H (2021, March 11) Syria: oil refinery attacks raise fears of 'grave escalation'. Al Jazeera.

Crisis Group (2018) Syria's Idlib wins welcome reprieve with Russia-Turkey deal. Retrieved from: https://www.crisisgroup.org/middle-east-north-africa/eastern-mediterranean/syr ia/syrias-idlib-wins-welcome-reprieve-russia-turkey-deal. [Accessed 24 March 2021]

Crisis Group (2020, May 15) Silencing the guns in Syria's Idlib. Middle East Report $\mathrm{N}^{\circ}$ 213. International Crisis Group.

Daily Sabah (2019, November 5) Support for President Erdoğan surges after Turkey's operation peace spring. Daily Sabah.

Del Torre V (2019) The EU response to Turkey's invasion of northern Syria. Retrieved from: https://www.egic.info/eu-response-to-turkey-in-syria. [Accessed 25 March 2021]

Emmott R (2019, October 14) EU governments limit arms sales to Turkey but avoid embargo. Reuters.

Erdogan RT (2021, March 15) The West should help Turkey end Syria's Civil War. Bloomberg.

Erkmen S (2020) Security, stability, and counter-terrorism in Idlib: a Turkish perspective. Syria Transition Challenges Project Discussion Paper 29. The Geneva Centre for Security Policy (GCSP). 
European Commission (2020) EU signs final contracts under the $€ 6$ billion budget of the facility for refugees in Turkey. Retrieved from: https://ec.europa.eu/neighbourhoodenlargement/news_corner/news/eu-signs-final-contracts-under-\%E2\%82\%AC6-billi on-budget-facility-refugees-turkey_en. [Accessed 2 January 2021]

European Parliament (2019) Turkey's military operation in Syria and its impact on relations with the EU. EPRS-Briefing-642284.

France24 (2020, March 11) Vowing to keep border open, Turkey's Erdogan compares Greeks to Nazis. Francce24.

Frantzman SJ (2021) NYT accused of whitewashing Turkey's Afrin occupation. Retrieved from: https://www.jpost.com/middle-east/nyt-accused-of-whitewashing-turkeys-afri n-occupation-659199. [Accessed 15 March 2021]

Gall C (2021, February 16) In Turkey's safe zone in Syria, security and misery go hand in hand. The New York Times.

Gridneff MS, Gall C (2020, February 29) Erdogan says, 'we opened the doors,' and clashes erupt as migrants head for Europe. New York Times.

Gurbuz M (2018) False hopes? Prospects for political inclusion in Rojava and Iraqi Kurdistan. Retrieved from: https://www.bakerinstitute.org/media/files/files/28e9244 4/ bi-brief-090518-cme-carnegie-gurbuz.pdf. [Accessed 15 April 2021]

Haid H (2018, February 12) Why did Russia abandon Afrin? Middle East Eye.

Iddon P (2019) Why Turkey is building a wall around Syria's Afrin. Retrieved from: https://ahvalnews.com/syrian-war/why-turkey-building-wall-around-syrias-afrin. [Accessed 24 January 2021]

Jennequin A (2020) Turkey and the weaponization of Syrian refugees. Policy Brief. Brussels International Center.

Kardaş Ş (2020) Turkey and the Idlib crisis: lingering dilemmas and future prospects. Turkish Policy Quarterly 19(2): 112-119.

Kasapoglu C (2017, February 3) Operation Euphrates Shield: progress and scope. Al Jazeera.

Khalifa D, Bonsey N (2021, February 3) In Syria's Idlib, Washington's chance to reimagine counter-terrorism. Crisis Group Report.

Kizilkaya Z, Hamdi S, Salman M (2021) The Syrian conflict after a decade: the survival strategy of Damascus and its implications for the EU. Retrieved from: https://brusse ls-school.be/publications/other-publications/syrian-conflict-after-decade-survival-stra tegy-damascus-and-its. [Accessed 30March 2021]

Lister C (2020, May 1) Is Idlib set for internal strife? Middle East Institute .

Lister C, Feltman J (2021) How Putin is starving Syria - and what Biden can do. Retrieved from: https://www.politico.com/news/magazine/2021/03/24/how-putin-isstarving-syria-and-what-biden-can-do-477685. [Accessed 1 April 2021]

Medina A (2020) Syria's 2020 in a nutshell, and what to expect for 2021? Retrieved from: https://syriadirect.org/syrias-2020-in-a-nutshell-and-what-to-expect-for-2021-2/. [Accessed 23 March 2021]

MFA Turkey (2021) PKK. Turkish Ministry of Foreign Affairs Official Web Site. Retrieved from: http://www.mfa.gov.tr/pkk.en.mfa. [Accessed 28 March 2021]

Moubayed S (2020) Why Erdogan is not serious about eliminating Hayat Tahrir al-Sham. Retrieved from: https://eeradicalization.com/why-erdogan-is-not-serious-about-elimi nating-hayat-tahrir-al-sham/. [Accessed 25 March 2021]

Mutter P (2020) The weaponization of the Syrian refugee crisis. Retrieved from: https://ris kline.com/the-weaponization-of-the-syrian-refugee-crisis/. [Accessed 29 March 2021]

Orhan O (2019) Suriye'de Guvenli Bolge Tartismalari (Debates on safe zones in Syria). Center for Middle Eastern Studies no. 92. 
Ozkizilcik O (2021, March 18) Turkey's response to Russian attack in Syria safe-zone is a milestone. TRT World.

Schmitt E (2020, September 24) U.S. Commandos use secretive missiles to kill Qaeda leaders in Syria". New York Times.

Semenov K (2021, February 18) Does 'Syrian trio' of Russia, Iran and Turkey have a future? Al Monitor.

Soldatkin V, Kiselyova M (2020, March 5) Russia, Turkey agree ceasefire deal for Syria's Idlib. Reuters.

Stanicek B (2019) Turkey's military operation in Syria and its impact on relations with the $E U$. European Parliamentary Research Service (EPRS).

SUDKOM (2021) Suriye Destek ve Koordinasyon Merkezi (Syria Support and Coordination Center). Retrieved from: http://sudkom.com/. [Accessed 28 March 2021]

Suriye Gundemi (2018) TSK Idlib Bölgesinde 12. Gözlem Noktasını Kurdu (Turkey established its $12^{\text {th }}$ observation post in Idlib). Retrieved from: https://www.suriyegun demi.com/tsk-idlib-bolgesinde-12-gozlem-noktasini-kurdu. [Accessed 24 March 2021]

Suriye Gundemi (2021) Suriye'de Gida Fiyatlari (Food prices in Syria). Retrieved from: https://www.suriyegundemi.com/suriye-de-gida-fiyatlari. [Accessed 12 March 2021]

SYRIAHR (2020) Al-Bab blast | Nearly 15 people killed and wounded in car-bomb explosion. Retrieved from: https://www.syriahr.com/en/193220/. [Accessed 18 January 2021]

SYRIAHR (2021) New York Times condemned, lauded for report on Turkey's occupation of Afrin. Retrieved from: https://www.syriahr.com/en/205483/. [Accessed 15 March 2021]

Temizer S, Tok L, Kako A (2019, September 25) Türkiye 3 milyon Suriyeli için güvenli bölge önerdi (Turkey proposed safe zones for 3 million Syrians). Anatolian Agency.

UNSC (2012) Identical letters dated 5 July 2012 from the Secretary-General addressed to the President of the General Assembly and the President of the Security Council. Retrieved from: https://digitallibrary.un.org/record/730361. [Accessed 18 February 2021]

UNSC (2021) Letter dated 21 January 2021 from the chair of the Security Council Committee concerning Da'esh, Al-Qaida and associated individuals, groups, undertakings and entities. Retrieved from: https://undocs.org/pdf?symbol=en/S/20 21/68. [Accessed 26 March 2021]

Uras U (2019, November 8) Turkey's Operation Peace Spring in northern Syria: one month on. Al Jazeera.

VanOpdorp D (2020) EU remains committed to refugee pact with Turkey. Retrieved from: https://www.infomigrants.net/fr/post/23319/eu-remains-committed-to-refugeepact-with-turkey. [Accessed 29 March 2021]

Waters G (2020) The Syrian regime's combat losses in Spring 2020, and what lies ahead. Middle East Institute Policy Paper.

Yackley AJ (2019, September 25) Erdogan pushes Syrian safe zone at UN. Al Monitor.

Yesiltas M (2018) Turkey's strategic reasoning behind Operation Olive Branch. SETA Perspective 34.

Yesiltas M (2019) Turkish strategic alternatives for the North East of Syria. Syria Transition Challenges Project. The Geneva Centre for Security Policy (GCSP).

Yesiltas M (2020) Deciphering Turkey's assertive military and defense strategy: objectives, pillars, and implications. Insight Turkey 22(3): 89-114.

Yesiltas M, Seren M, Özçeli N (2017) Operation Euphrates shield implementation and lessons learned. Seta | Foundation for Political, Economic and Social Research. 
